\title{
COMBINING SERVQUAL AND IMPORTANCE-PERFORMANCE ANALYSIS TO MEASURE SERVICE QUALITY IN A HOTEL IN TOBRUK, LIBYA: \\ A SUGGESTION FOR PRACTITIONERS
}

Mirwan Surya Perdhana ${ }^{1}$

Omelkhair Ali Ahshen²

\section{1,2,3 Master of Management Program, Department of Management, Universitas Diponegoro, Indonesia}

\begin{abstract}
The aim of this study is to present the alternative method in measuring service quality. This study investigates the service quality literatures and introduces the practical method to measure the service quality. To measure service quality, a modified SERVQUAL instrument was distributed towards 100 guest of an international hotel located in Tobruk, Libya. The ImportancePerformance Analysis was conducted based on the questionnaire results. Managerial implications and further research opportunities were also discussed.
\end{abstract}

Keywords: Service quality, Importance-Performance Analysis, Hospitality Industry.

\section{RESEARCH BACKGROUND}

Over the years, researchers have focused on developing the service quality instrument in various sectors (Perdhana, Magnadi, Dirgantara \& Arfinto, 2017). With the increased demand of better customer service in many industries, service has becomes one of the most important aspect to enable organization achieving sustainable competitive advantage (Wu, Liao, Hung, \& Ho, 2012). Quality service could lead to customer loyalty, image enhancement, cost reduction and business performance improvement (Choi \& Chu, 2001; Ramanathan \& Ramanathan, 2011). As the result, practitioners and academic researchers' attention were focused on how customers perceive service quality. From the customer point of view, quality service represent positive perception and leads to purchase intentions (Gummesson, 1991).

Pioneering research on service quality (e.g., Parasuraman, Zeithaml, \& Berry, 1985, 1988; Cronin \& Taylor, 1994; Zeithaml, Berry, \& Parasuraman, 1996) 
have been focused on different aspects of service quality, but finally able to reach the same conclusion. According to those research, service quality is as an attitude resulted from the comparison of customer expectations with the perception of performance (Parasuraman et al., 1985, 1988).

Researchers have also identified that there were differences of the service quality measurement between service and manufacturing industry. The quality of service could not be measured in the same way as the quality of manufactured goods (Crick \& Spencer, 2011). Measuring service is more complex compared to products, since the customer have a direct experience with the service provider (Ghobadian, Speller, \& Jones, 1994). In the service industry, quality is the comparison between customer's expectations of service and their perception of the service performance (Grönroos, 1984; Lewis \& Boom, 1983).

There were debates on the conceptualization and on the applicability of service quality concept in different context. It is argued that there is a need to develop country-specific measurement for service quality (Crick \& Spencer, 2011; Karatepe, Yavas, \& Babakus, 2005), especially since a service quality instrument might not be applicable in different culture or industry (Hsieh \& Tsai, 2009; Salazar, Xosta, \& Rita, 2010). Since the original SERVQUAL developed by Parasuraman et al. (1988) were tested only in banking, electronic repair, credit card, long-distance call and sales service, the instrument need to be developed in specific industry sector. Such inquiry has been answered and specific service quality instrument were developed; for example HedPERF (Abdullah, 2006), Retail Service Quality Scale (Daholkar et al., 1996), DINESERV (Stevens et al., 1995) and e-GovQual (Papadomichelaki \& Mentzas, 2012). A modified service quality instrument was also developed, for example instrument for hospitality industries (Akibaba, 2006) which focus on several attributes e.g., improper standards, distribution channels, reliability and consistency, face-to-face interaction, and fluctuating demand. Many authors have agreed that these attributes were important for measuring service quality (Akibaba, 2006; Sohrabi, Vanani, Tahmaswbipur, \& Fazil, 2012).

Specific in the hospitality industry, the SERVQUAL instrument (Parasuraman et al., 1988) was considered applicable and has been widely used to help the organization measuring the guests' satisfaction. Nevertheless, this study argue that combining the SERVQUAL scale with Importance-Performance Analysis (IPA) and the presentation using radar diagram could serve as a more superior method to measure the guests' satisfaction. IPA is used to gain deeper understanding about the perception of service users on the quality of the service. IPA is a very useful tool in describing the position of quality attributes so that organization could make better business decision according on the results. On the 
other hand, presenting the SERVQUAL results in the form of radar diagram will give better point of view on which service aspect needs to be improved.

Although the use of modified SERVQUAL instrument could be used to measure service quality in hospitality sector, this study argued that the use of IPA could improve the accuracy of service quality measurement and provide managers with useful information on what aspect needs to be focused based on the result. IPA analysis could be conducted using Cartesian diagram to demonstrate the service attributes that are considered important by consumers. By including all attributes that affect customer satisfaction, Cartesian diagram can be used to explain the importance and performance of service attributes and identify what action is required (Supranto, 2006). By utilizing IPA, management could obtain deeper insights for developing marketing strategies (Matrilla \& James, 1977). Thus, the aim of this research is to present a practical method to measure service quality in the hospitality industry using the combination of SERVQUAL and IPA.

\section{METHODS}

This study utilized literature review to present the practical method to measure service quality in hotel industry. Two instruments were used, which are SERVQUAL instrument and IPA. The following section will provide the example on how to conduct the SERVQUAL and IPA analysis in real business practice. List of SERVQUAL indicators specific for hospitality industry was adopted from Akibaba (2006) study. The instrument was translated into Arabic language. The samples were 100 respondents who have recently finished their stay at an international hotel located in Tobruk, Libya. The data were collected from August until September 2017.

The data were analyzed by comparing the Performance (actual) and Importance (expected) followed by the IPA analysis. Firstly, indicators from each

dimensions were summed up and aggregated for both performance and importance section. Afterwards, data were presented in radar diagram and were put into IPA quadrant.

\section{RESULTS AND DISCUSSION}

The calculation result for each service quality dimension is presented in Table 1. According to the table, there were some differences between the performance (reality) and importance (expectation) for each service quality dimensions. Such difference could be investigated further by breaking down each service quality indicators and present it in radar diagram presented in Figure 1. 
After further scrutiny towards the indicators of each service quality dimension (Figure 2), there was some gap that could be identified. Firstly, it was revealed in the tangible dimension that the hotel atmosphere was not as the guests expected. Within the assurance dimension, some indicators were beyond the guests' expectation: the ability to handle guest complaints and the knowledge of the hotel employees. Nevertheless, the hotel was considered lack of friendliness and convenience. For reliability and responsiveness dimensions, almost all indicators were below expectation. Hotel guests did not consider the ease of access toward the hotel, however, they did consider attention, and operating hour and safety provided by the hotel were above expectations.

After calculating and presenting the SERVQUAL results, the IPA analysis was conducted. The IPA analysis was based on Table 1 and was depicted in Figure 1. It was interesting that almost all service quality dimension were positioned in the second quadrant (keep up the good work), which means that all service offered by the hotel has been considered acceptable.

Table 1

SERVQUAL Results

\begin{tabular}{lcc}
\hline Dimensions & Performance & Importance \\
\hline Tangible & 3,68 & 4,25 \\
Reliability & 3,01 & 4,12 \\
Responsiveness & 4,08 & 4,27 \\
Assurance & 4,01 & 4,26 \\
Emphaty & 3,99 & 4,21 \\
\hline Average: & $\mathbf{3 . 7 5}$ & $\mathbf{4 . 2 2}$ \\
\hline
\end{tabular}

Figure 1

Importance-Performance Analysis

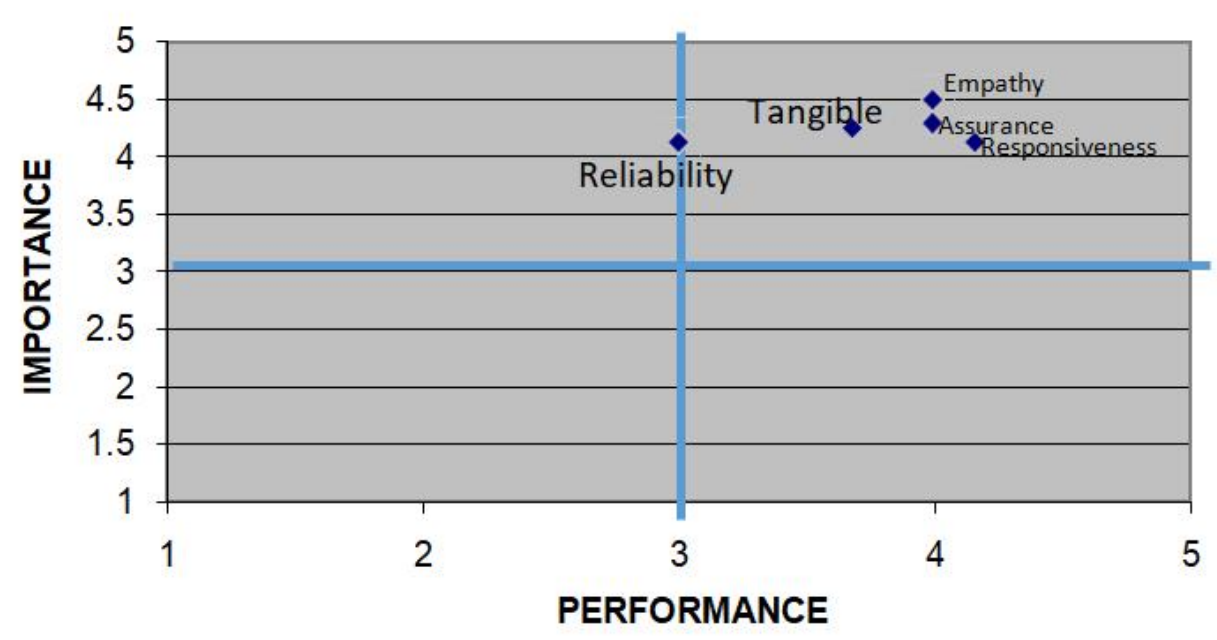


Figure 2

Radar Diagram for each Service Quality Dimensions

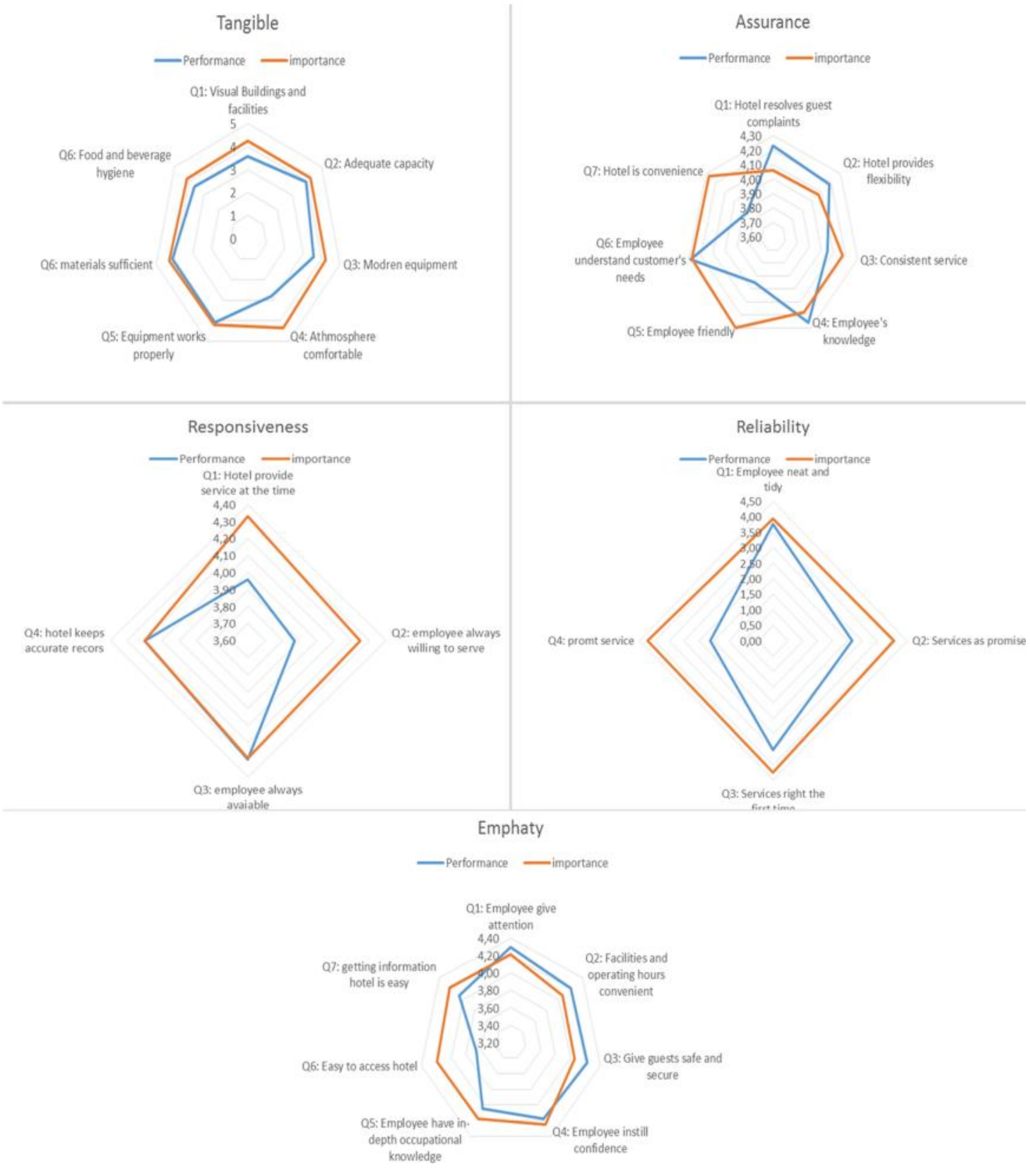

It was interesting that despite the gap in the radar diagram, which demonstrated the difference between the performance and expectation, the hotel service quality level was considered as acceptable. Such finding would not be realized if the indicators of each dimension were not presented along with the IPA 
analysis. Thus, radar diagram would function to highlight the gap between importance and performance of the service quality in the observed organization. The gap could be used as information for managers to conduct continuous improvement on the specific aspect of service quality.

\section{CONCLUSIONS}

It is understandable that service quality is an important factor that needs to be given attention in an organization. To measure service quality, this study has present several steps in order to measure service quality accurately. SERVQUAL instrument could be used as a guideline to obtain information about the actual and expected performance of service quality in an organization. However, the presentation of SERVQUAL results needs to be break down into each dimension, presenting the radar diagram and IPA diagram in order to obtain a better point of view of the service quality level of an organization.

This study could be used and implemented by manager, especially in hotel industries to give better attention to their service quality. If followed correctly, the service quality level of the organization could be improved by following steps presented in this study.

\section{REFERENCES}

Abdullah, F. (2006). The development of HEdPERF: a new measuring instrument of service quality for the higher education sector. International Journal of Consumer Studies, 30(6), 569-581. https://doi.org/10.1111/j.1470-6431.2005.00480.x

Akibaba, A. (2006). Measuring service quality in the hotel industry: a study in a business hotel in Turkey. Hospitality Management, 170-192.

Carrillat, F.A., Jaramillo, F. and Mulki J.P., (2007), "The validity of the SERVQUAL and SERVPERF scales: A meta-analytic view of 17 years of research across five continents", International Journal of Service Industry Management, 18(5), 472-490

Crick, A. P., \& Spencer, A. (2011). Hospitality quality: new directions and new challenges. International Journal of Contemporary Management, 23, 214230.

Cronin, J. J., \& Taylor, S. A. (1992). Measuring Service Quality: A Reexamination and Extension. Journal of Marketing, 56(3), 55-68. https://doi.org/10.2307/1252296 
Dabholkar, P. A., Thorpe, D. I., \& Rentz, J. O. (1996). A Measure of Service Quality for Retail Stores: Scale Development and Validation. Journal of the Academy of Marketing Science, 24(3), 3-16.

Grönroos, C. (1984). A Service Quality Model and its Marketing Implications. European Journal of Marketing, 18(4), 36-44.

https://doi.org/10.1108/EUM0000000004784

Gummesson, E. (1991). Service quality: a holistic view. In Brown, S.W., Gummesson, E., Edvardsson, B., \& Gustavson, B. (Eds.), Service quality (pp. 3-22). Lexington, MA: Lexinton Books.

Hsieh, A., \& Tsai, C. (2009). Does national culture really matter? Hotel service perceptions by Taiwan and American tourists. International Journal of Culture, Tourism and Hospitality Research, 15, 54-69.

Karatepe, O. M., Yavas, U., \& Babakus, E. (2005). Measuring service quality of banks: scale development and validation. Journal of Retailing and Consumer Services, 12(5), 373-383.

Lewis, R. C., \& Boom, B. . (1983). The Marketing Aspects of Service. In Berry, L., Shostack, G. and Upah, G. (Eds), "Emerging Perspective on Services Marketing" American Marketing Association (pp. 99-107).

Martilla, John A., and John C. James. (1977). Importance-Performance Analysis. Journal of Marketing, Vol. 41, No. 1 (Jan., 1977), pp. 77-79.

Papadomichelaki, X., \& Mentzas, G. (2012). e-GovQual: A multiple-item scale for assessing e-government service quality. Government Information Quarterly, 29(1), 98-109. https://doi.org/http://dx.doi.org/10.1016/j.giq.2011.08.011

Parasuraman, A., Zeithaml, V. A., \& Berry, L. L. (1985). A Conceptual Model of Service Quality and Its Implications for Future Research. Journal of Marketing, 49(4), 41-50. https://doi.org/10.2307/1251430

Parasuraman, A., Zeithaml, V. A., \& Berry, L. L. (1988). Servqual: AmultipleItem scale for measuring consumer perceptions of Service Quality. Journal of Retailing, 64(1), 12-40.

Perdhana, M.S., Magnadi, R.H., Dlrgantara, I.M.B., Arfinto, E.D. (2017). Perbandingan instrumen kuantitatif untuk mengukur kualitas layanan. Jurnal Studi Manajemen Organisasi 14 (2017) Juni, 31-40. http://ejournal.undip.ac.id/index.php/smo 
Salazar, A., Xosta, J., \& Rita, P. (2010). A service quality evaluation scales for the hospitality sector: Dimensions, attributes and behavioural intentions. Worldwide Hospitality and Tourism Themes, 2(4), 46-57.

Sohrabi, B., Vanani, I. R., Tahmaswbipur, K., \& Fazil, S. (2012). An exploratory analysis of hotel selection factors: A comprehensive survey of Tehran hotels. International Journal of Hospitality Management, 31(1), 96-106.

Stevens, P., Knutson, B., \& Patton, M. (1995). Dineserv: A tool for measuring service quality in restaurants. The Cornell Hotel and Restaurant Administration Quarterly, 36(2), 5-60. https://doi.org/http://dx.doi.org/10.1016/0010-8804(95)93844-K

Supranto. (2006). Measuring Customer Satisfaction Level, Rineka Cipta, Jakarta

Wu, C. H., Liao, H., Hung, K., \& Ho, Y. (2012). Service guarantees in the hotel industry: Their effects on consumer risk and service quality perceptions. International Journal of Hospitality Management, 31(3), 757-763

Zeithaml, V. A., Berry, L. L., \& Parasuraman, A. (1996). "The behavioral consequences of service quality,." Journal of Marketing, 60(2), 31-46. 